\title{
Physical Inactivity Changes in Croatia: the CroHort Study
}

\author{
Eduard Missoni ${ }^{1}$, Josipa Kern ${ }^{2}$ and Ivan Missoni ${ }^{3}$ \\ ${ }^{1}$ University of Zagreb, Faculty of Traffic Science, Zagreb, Croatia \\ ${ }^{2}$ University of Zagreb, School of Medicine, »Andrija Štampar« School of Public Health, Zagreb, Croatia \\ ${ }^{3} \mathrm{PhD}$ candidate, BA in History and English Language and Literature, Samobor, Croatia
}

\begin{abstract}
A B S T R A C T
The aim of this paper was to compare the surveys conducted respectively in 2003 and 2008 within the Croatian Adult Health Cohort Study (CroHort) regarding the physical activity/inactivity of the inhabitants of the Republic of Croatia. The collected data show a significant decline in the intensity of physical activity in 2008 with regards to 2003, regarding the way of getting to work (60.7\%), the level of physical strain at work (72.2\%), and the frequency of physical activity taken in the subjects' spare time (55.8\%). In order to prevent the risk of cardiovascular diseases and to raise the public awareness of the potential health threat physical inactivity poses, a number of thoroughly conceived health promotion strategies should be implemented, which would equally encompass all the segments of Croatian society.
\end{abstract}

Key words: public health, physical activity, physical inactivity changes, CroHort study

\section{Introduction}

Several decades ago, epidemiological researches have ascertained the existence of numerous risk factors for developing atherosclerosis, that is, the heart and vascular disease. The development of these diseases is particularly accelerated if one has more than one risk factor at the same time ${ }^{1}$. These diseases, which in the first place imply heart attack and stroke, represent the »killer No. 1« of contemporary man, claiming 17.1 million lives per year (every other inhabitant in the so-called Industrial World $)^{2}$. In concordance with that fact, cardiovascular diseases in Croatia were the leading cause of death with 25876 deceased persons, with the share of $49.6 \%$ in the overall mortality in our country in $2009^{3}$. A crucial risk factor for the appearance and development of some kinesiologically sensitive diseases, among which the coronary heart disease undisputedly dominate, is physical inactivity ${ }^{4}$. According to the World Health Organization, engaging in physical activity for at least 30 minutes every day of the week will help to prevent heart attacks and strokes $^{2}$.

\section{Subjects and Methods of Data Collecting}

The Croatian Adult Health Cohort Study (CroHort) was the source of data, encompassing the representative sample of persons from 18 years old and older, who live in their own household. The surveys from 2003 and 2008 respectively were conducted by previously educated expert personnel, led by the people specialized in the area of public health and epidemiology, under supervision of specialists of preventive profession, Andrija Štampar School of Public Health, Zagreb and Croatian National Institute for Public Health ${ }^{5}$.

After arranging the survey questionnaire forms, all of the data were pondered, thus enabling a database to be set up within the framework of the conducted study, which in turn consisted of 3229 subjects.

Survey questionnaire forms consisted of three following questions, which relate to the physical activity/inactivity of the subjects:

1. How do you get to work?

2. How physically strenuous is your work?

3. Are you physically active in your spare time?

\section{Results}

Tables 1-6 depict a five-year change in physical inactivity measured by the three variables described in the text. Changes in the way of getting to work are presented

Received for publication September 1, 2011 
TABLE 1

GETTING TO WORK IN 2003 AND 2008

\begin{tabular}{lcccc}
\hline Getting to work & \multicolumn{4}{c}{2003} \\
\cline { 2 - 5 } & $\begin{array}{c}\text { Does not } \\
\text { work/works } \\
\text { at home }\end{array}$ & $\begin{array}{c}\text { by car/ } \\
\text { public } \\
\text { transport }\end{array}$ & $\begin{array}{c}\text { walks/ } \\
\text { cycles }\end{array}$ & Total \\
\hline $\begin{array}{l}\text { Does not work/ } \\
\text { Works at home }\end{array}$ & 2057 & 185 & 103 & 2345 \\
$\quad$ Col Pct & 88.1 & 31.8 & 37.5 & \\
By car/public & 194 & 350 & 64 & 608 \\
transport & 8.3 & 60.2 & 23.3 & \\
$\quad$ Col Pct & 85 & 46 & 108 & 239 \\
Walks/cycles & 3.6 & 7.9 & 39.3 & \\
$\quad$ Col Pct & 2336 & 581 & 275 & 3192 \\
\hline Total & & & & \\
\hline
\end{tabular}

TABLE 2

CHANGES IN GETTING TO WORK

\begin{tabular}{lc}
\hline Without change & $78.8 \%$ \\
\hline $\begin{array}{l}\text { Improvement } \\
\quad \text { (walks/cycles in 2008) }\end{array}$ & $4.5 \%$ \\
$\begin{array}{l}\text { Decline } \\
\quad \text { (drives/does not work in 2008) }\end{array}$ & $60.7 \%$ \\
\hline
\end{tabular}

TABLE 3

PHYSICALLY STRENUOUS JOB IN 2003 AND 2008

\begin{tabular}{lcccc}
\hline $\begin{array}{l}\text { Physically } \\
\text { strenuous job }\end{array}$ & \multicolumn{5}{c}{2003} \\
\hline 2008 & Easy & medium hard & hard & Total \\
\hline Easy & 971 & 569 & 97 & 1637 \\
Col Pct & 71.7 & 46.5 & 28.7 & \\
Medium hard & 348 & 556 & 147 & 1051 \\
Col Pct & 25.7 & 45.4 & 43.5 & \\
Hard & 36 & 99 & 94 & 2688 \\
Col Pct & 2.7 & 8.1 & 27.8 & \\
\hline Total & 1355 & 1224 & 338 & 2917 \\
\hline
\end{tabular}

in Tables 1 and 2 . In $78.8 \%$ of the subjects nothing had changed in their way of getting to work. A decreased physical activity in 2008 in relation to 2003 was evident in as much as $60.7 \%$ of the subjects, whereas only $4.5 \%$ of them made a positive change in 2008 , by either walking or cycling to work.

Changes in the intensity of physical activity measured by the physical strain at the workplace were presented in Tables 3 and 4 . In $55.6 \%$ of the subjects nothing had changed. A decline in physical activity in 2008 compared with 2003 occurred in as much as $72.2 \%$ of the subjects, whilst only $18.7 \%$ of the subjects increased their physical activity - the ones that in 2008 had physically more strenuous jobs than in 2003.

Changes in the intensity of physical activity in the subjects' spare time are represented in Tables 5 and 6 . In
TABLE 4

CHANGES IN PHYSICALLY STRENUOUS JOB

\begin{tabular}{lc}
\hline Without change & $55.6 \%$ \\
\hline $\begin{array}{l}\text { More strenuous } \\
\quad \text { (harder job in 2008) }\end{array}$ & $18.7 \%$ \\
$\begin{array}{l}\text { Less strenuous } \\
\quad(\text { easier job in 2008) }\end{array}$ & $72.2 \%$ \\
\hline
\end{tabular}

TABLE 5

PHYSICAL ACTIVITY/INACTIVITY IN ONE'S SPARE TIME IN 2003 AND 2008

\begin{tabular}{lcccc}
\hline $\begin{array}{l}\text { Physical activity/ } \\
\text { inactivity in one's } \\
\text { spare time }\end{array}$ & \multicolumn{5}{c}{2003} \\
\hline 2008 & Never & sometimes & regularly & Total \\
\hline Never & 720 & 300 & 409 & 1429 \\
Col Pct & 58.5 & 38.5 & 34.0 & \\
Sometimes & 262 & 250 & 263 & 775 \\
Col Pct & 21.3 & 32.1 & 21.8 & \\
Regularly & 248 & 230 & 532 & 1010 \\
Col Pct & 20.2 & 29.5 & 44.2 & \\
\hline Total & 1230 & 780 & 1204 & 3214 \\
\hline
\end{tabular}

TABLE 6

CHANGES IN PHYSICAL ACTIVITY/INACTIVITY IN ONE'S SPARE TIME

\begin{tabular}{lc}
\hline Without change & $46.7 \%$ \\
\hline $\begin{array}{l}\text { Improvement } \\
\quad \text { (more physical activity in 2008) }\end{array}$ & $36.8 \%$ \\
$\begin{array}{l}\text { Decline } \\
\quad \text { (less physical activity in 2008) }\end{array}$ & $55.8 \%$ \\
\hline
\end{tabular}

$46.7 \%$ of the subjects nothing had changed. Decreased physical activity in 2008, compared with 2003 occurred in as much as $55.8 \%$ of the subjects, whilst $36.8 \%$ increased their physical activity - the ones who 2008 were physically more active in their spare time than in 2003.

\section{Discussion}

Previous researches have shown that the pace of life recently, especially among people living in urban areas, causes decreased physical activity of the Croatian population $^{6}$. That negative trend has extended well into 2008, where, according to the CroHort Study, as much as $60.7 \%$ of the subjects were physically less active than in 2003 , whilst at the same time only $4.5 \%$ became physically more active, either by walking or cycling to work. The decrease in physical activity is also manifested in the comparison of the physical strain in the workplace, where the number of people who in 2008 had physically harder jobs than in 2003 (18.7\%), was three and a half times smaller than then those who had meanwhile 
exchanged a harder job for an easier one (72.2\%). Ultimately, despite the fact that a decreased physical activity was recorded in $55.8 \%$ of the subjects, the knowledge that every third subject (36.8\%) from 2008 has increased his or hers activity with regards to 2003 , yet provides a more optimistic perspective of conscious efforts which the inhabitants of Croatia willingly put into leading a healthier lifestyle. One of the most popular and widespread recreational physical activity is cycling, both in the highly developed and underdeveloped countries, as well as in Croatia ${ }^{7,8}$. It should be nevertheless noted that bicyclists are minimally or insufficiently protected traffic participants, and that their activity could result in unwanted injuries ${ }^{9,10}$.

\section{Conclusion}

The results of the survey conducted in the Republic of Croatia on physical activity/inactivity and especially about the one done in one's spare time, point to the conclusion that because of the decreased physical activity of the population, the risk of cardiovascular diseases increases. In order to prevent the risk of those diseases and to raise the public awareness of the potential health threat physical inactivity poses, a number of thoroughly conceived health promotion strategies should be implemented, which would equally encompass all the segments of Croatian society.

\section{Acknowledgements}

This article was prepared as a part of scientific project »Regionalism of cardiovascular behavioural risk factors model of intervention « (108-1080135-0264) supported by Ministry of Science, Education and Sport of the Republic of Croatia.

\section{R E F E R E N C E S}

1. HARDMAN AE, STENSEL DJ, Physical activity and health - evidence explained (Routledge, Taylor and Francis Group, London and New York, 2004). - 2. WHO, Fact sheet N ${ }^{\circ} 317$, January 2011. - 3. Hrvatski zavod za javno zdravstvo, Kardiovaskularne bolesti u Republici Hrvatskoj, accessed on 17.08.2011. Available from: http://www.hzjz.hr/epidemiologija/kron_mas/kvb.htm - 4. VUORI I, Kinesiology, 36 (2004) 123. - 5. VULETIĆ S, KERN J, Hrvatska znanstvena anketa 2003, Hrvatski časopis za javno zdravstvo (2005), accessed on 21.08.2011. Available from: http:/

/www.hcjz.hr/clanak.php?id=12389 - 6. MIŠIGOJ-DURAKOVIĆ M, HEIMAR S, GREDELJ M, HEIMER Ž, SORIĆ M, Acta Med Croat, 61 (2007) 253. - 7. NIKOLIĆ N, MISSONI E, MEDVED G, J Travel Med, 12 (2005) 53. - 8. MISSONI E, KERN J, Croat Med, J, 44 (2003) 610. - 9. TIN TIN S, WOODWARD A, AMERATUNGA S, BMC Public Health, 30 (2010) 655. - 10. HEESCH KC, GARRARD J, SAHLQVIST S, Accid Anal Prev, 43 (2011) 2085.

\section{E. Missoni}

University of Zagreb, Faculty of Traffic Science, Vukeliceva 4, 10000 Zagreb, Croatia

e-mail: emissoni@fpz.hr

\section{PROMJENE U TJELESNOJ NEAKTIVNOSTI U HRVATSKOJ - STUDIJA CroHort}

\section{S A Ž E T A K}

Ciljem je ovoga rada usporediti ankete provedene 2003. i 2008. godine u sklopu Hrvatske kohortne studije kardiovaskularnog zdravlja (CroHort) vezane uz tjelesnu aktivnost/neaktivnost stanovnika Republike Hrvatske. Prikupljeni podatci ukazuju na značajan pad intenziteta tjelesne aktivnosti 2008. u odnosu na 2003, prema načinu odlaska na posao (60,7\%), razini tjelesnog napora na radnom mjestu $(72,2 \%)$, i učestalosti tjelesne aktivnosti poduzimane u slobodno vrijeme ispitanika $(55,8 \%)$. Kako bi se spriječio rizik od srčano-žilnih bolesti i podigla svijest javnosti o potencijalnoj zdravstvenoj prijetnji koju predstavlja tjelesna neaktivnost, niz podrobno osmišljenih strategija u svrhu promicanja zdravlja trebao bi biti proveden, a koji bi podjednako obuhvatio sve slojeve hrvatskoga društva. 